Exploring the Use of Seattle's Farmers' Market Incentive Program ("Fresh Bucks") by Household Food Security Levels

\title{
Elizabeth Hulbrock
}

\author{
A thesis \\ submitted in partial fulfillment of the \\ requirements for the degree of
}

Master of Public Health

University of Washington

2015

\author{
Committee: \\ Jennifer Otten, Chair \\ Emilee Quinn \\ Program Authorized to Offer Degree: \\ School of Public Health-Nutritional Sciences
}


(C) Copyright 2015

Elizabeth Hulbrock 
University of Washington

\begin{abstract}
Exploring the Use of Seattle's Farmers' Market Incentive Program ("Fresh Bucks") by Household Food Security Levels
\end{abstract}

Elizabeth Hulbrock

Chair of the Supervisory Committee:

Dr. Jennifer Otten, PhD, RD

Nutritional Sciences

\title{
Introduction
}

Farmers market incentive programs such as the Fresh Bucks program in Seattle, Washington aim to improve healthy food access and food security amongst low-income individuals. The objective of this study was to compare Fresh Bucks access and associated shopping behaviors across food security levels of high/marginal, low, and very low food security.

\section{Methods}

Researchers surveyed a convenience sample of Fresh Bucks users at the farmers market prior to shopping, after shopping at the farmers market later that same day, and one to two months later via telephone. Responses to the six-question short form of the U.S. Household Food Security Survey Module were used to classify subjects as high/marginal, low, or very low food security. We analyzed differences in demographics and farmers market shopping behaviors by food security levels.

\section{Results}

Slightly less than half of all subjects (45\%) reported high or marginal food security, $28 \%$ reported low food security and 28\% reported very low food security. Frequency of shopping at a farmers market when in season differed by food security status (Fisher exact $P=0.03$ ). Further examination of this relationship with a proportional odds regression model indicated no significant association. All other farmers market shopping 
behaviors included in the study demonstrated no significant differences by food security status.

\section{Conclusion}

Food security status amongst Fresh Bucks shoppers mirrors national trends. Participants use the Fresh Bucks program and farmers market in similar ways regardless of food security status. However, these relationships should be explored in a larger and more diverse population. 
TABLE OF CONTENTS

INTRODUCTION

METHODS

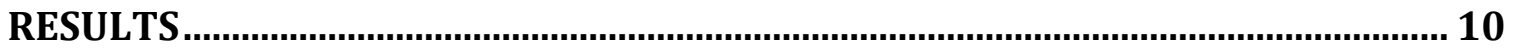

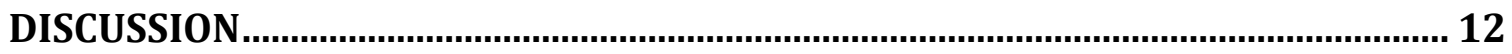

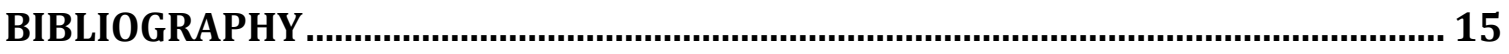

TABLES 


\section{INTRODUCTION}

In 2014, 17.4 million U.S. households experienced food insecurity. ${ }^{1}$ Food insecurity is defined as inadequate access to food due to lack of resources. Food insecurity can range in severity from very low to low food security and food insecure households may adjust food intake and meal patterns to varying degrees. In contrast, households with high or marginal food security may have food access difficulties but do not report significantly altering behaviors in response. In these households, food access problems exist but may remain limited to anxiety over food sufficiency. ${ }^{1,2}$

Many U.S. programs and policies exist to reduce food insecurity, including the Child and Adult Care Food Program (CACFP); the National School Lunch Program (NSLP); Supplemental Nutrition Assistance Program (SNAP); and Women, Infants and Children (WIC). ${ }^{3}$ Despite these programs, inequity persists in access to healthy, affordable foods and nutrition related health outcomes. Food insecure adults consume a diet of lower variety and rely more heavily on energy-dense foods while consuming less fruits, vegetables, and dairy products compared to food secure adults. ${ }^{4,5}$ These disparities likely contribute to the higher rates of obesity and nutrition-related chronic disease observed amongst individuals from food insecure households. ${ }^{6,7}$ Research also indicates that food insecure households may exhibit different shopping behaviors compared to food secure households. ${ }^{1,8}$

Recently, several cities have introduced farmers' market incentive programs to address diet quality in addition to sufficiency. In 2012, the Neighborhood Farmers Market Alliance (NFMA) began implementing one such program, known as Fresh Bucks, throughout 7 farmers markets in Seattle. In 2013, the City of Seattle began administering the program and it was expanded to all markets in the city (15). A primary goal of this program is to increase the purchase of healthy foods and improve food security status amongst low-income individuals. ${ }^{9}$ Individuals redeeming Supplemental Nutrition 
Assistance Program (SNAP) benefits at Seattle farmers markets receive a dollar for dollar match, up to $\$ 10$, to purchase fruits, vegetables, herbs, mushrooms, and vegetable starters. $^{9}$

To date, evaluations of Fresh Bucks and similar programs have demonstrated improved dietary and behavioral outcomes among users. ${ }^{10,11,12,13,14}$ Previous studies have described populations using incentive programs and measured changes in healthy food purchase and consumption, but to our knowledge none have specifically included a measure of participants' food security levels or investigated farmers market shopping behaviors as

they relate to food security. ${ }^{10-14}$ The relationship between Fresh Bucks and food security warrants further study to understand how access to the program and experience at the farmers market are impacted by food security status. This analysis addresses the following questions: What are the characteristics of Fresh Bucks users across different food security levels? How do Fresh Bucks shopping behaviors (i.e. shopping frequency, payment method, purchasing behaviors, and post-purchase behaviors) differ by food security level?

\section{METHODS}

This analysis uses a subset of data from a larger evaluation of the Fresh Bucks program in 2014 completed by the University of Washington Center for Public Health Nutrition, under contract with the City of Seattle. The University of Washington Institutional Review Board approved all study procedures. ${ }^{10}$

\section{Setting and Study Design}

Researchers surveyed Fresh Bucks users at three time points: 1) at the farmers market prior to shopping, 2) after shopping at the farmers market later that same day, and 3) one to two months later via telephone. From August through September 2014, trained researchers conducted face-to-face interviews of 191 Fresh Bucks users at 6 Seattle farmers markets (estimated refusal rate $<20 \%$ ). Although researchers did not document 
reasons for refusal, several individuals refused the survey due to limited English proficiency. Farmers markets were selected based on relatively high historical EBT transaction numbers and reported customer diversity. Trained researchers stood at the farmers market information booth and invited Fresh Bucks users to participate in the survey. Respondents were offered \$4-5 in additional farmers market currency if they returned to complete the post-shopping survey. Approximately $85 \%(n=163)$ returned to complete the post-shopping survey. Researchers also invited subjects to participate in a follow-up survey via a short phone call later in the year. Between October and November 2014, research assistants made up to three attempts to contact each individual who provided contact information. Of 163 individuals who provided contact information, 90 telephone surveys were completed. This corresponds to a $55 \%$ response rate and $47 \%$ of all individuals surveyed at the market. Respondents received a $\$ 5$ Target gift certificate in recognition of their participation.

\section{Survey Content}

The market pre-shopping survey included 26 questions pertaining to Fresh Bucks, SNAP, and farmers market use (including frequency and purchasing behaviors); typical fruit and vegetable consumption; perceived impact of the Fresh Bucks program; and demographic information. Pre-shopping surveys also included the six-question short form of the U.S. Household Food Security Survey Module, which is designed to categorize respondents into one of three household food security levels: high or marginal food security, low food security, or very low food security. ${ }^{15}$ Per tool guidelines, respondents with $0-1$ affirmative responses were classified as high or marginal food security. Those with 2-4 affirmative responses were classified as low food security, and subjects with 5-6 affirmative responses were considered very low food security.

The post-shopping market survey included 9 questions specific to market purchases and the likelihood of future program use. The 38-question telephone survey included many of the same questions as the market pre-shopping survey, including all food security survey questions, as well as additional questions that pertained to Fresh Bucks use since 
completion of the market survey, experience with Fresh Bucks produce, and future intentions to use the Fresh Bucks program. Subjects with incomplete responses to food security questions $(\mathrm{n}=19)$ were removed from the sample, resulting in a final sample size of 182 for the pre shopping market survey and 80 for the telephone survey.

\section{Variables of Interest}

Race, ethnicity, gender, language spoken at home, number of children, household size, age, education level, participation in other food assistance programs, monthly SNAP benefit amount, and length of time receiving SNAP were included as demographic variables. Fresh Bucks shopping behaviors in the survey included shopping frequency, purchasing behaviors, payment method, and post-purchase behaviors. Examples of survey questions pertaining to Fresh Bucks shopping behaviors include: "How often do you shop at farmers markets when they are in season?", "Would you say you buy the same amount of fruits and vegetables in a given month when you use the Fresh Bucks program, or more?", "Did you have any EBT currency or Fresh Bucks left over after shopping?", and "In general, how many of the fruits and vegetables that you bought with Fresh Bucks did you know how to prepare when you bought them?"

\section{Statistical Analysis}

Trained researchers entered all data into a web-based data entry interface, which provides output as an Excel file. Statistical analyses were conducted in R version 3.1.3. ${ }^{16} \mathrm{We}$ calculated descriptive statistics for subject demographic factors and market shopping behaviors by food security classification: high or marginal, low, and very low. Since food security level was measured during both the market and telephone surveys, we analyzed demographic and shopping characteristics by food security level such that both variables were measured at the same time point. Chi squared or fisher exact tests were used to determine whether demographic factors and farmers market shopping behaviors differed significantly between Fresh Bucks users by household food security classifications. 
Additionally, we ran unadjusted and adjusted proportional odds regression models to analyze the association (Odds Ratio [OR], 95\% Confidence Interval [CI]) between food security level and farmers market shopping frequency (categorized as first time, less than once a month, once or twice a month, and more than once a week). The OR is used to compare the odds of shopping frequency being greater than first time, less than once a month, and once or twice a month for individuals with high/marginal compared to very low food security. Covariates included market location, gender, number of children, household size, and language spoken at home. A $P$ value $<0.05$ was considered statistically significant.

\section{RESULTS}

\section{Characteristics of study respondents}

Overall demographic patterns were consistent amongst samples across all three surveys. Thus, in Table 1, we provide demographic characteristics for the 182 pre-market survey responses. Study participants were mostly white (65\%), English-speaking (84\%), female $(66 \%)$, between the ages of 18 and $50(74 \%)$, and childless $(76 \%)$. Of those with children, the number of children per household ranged from 1 to 6 . The mean household size was 2.4 (range:29), and nearly half (42\%) of respondents reported a single person household. Additionally, the majority of subjects (62\%) had obtained a college education or greater. These demographic trends differ from reported demographics of Seattle-wide SNAP users. The American Community Survey estimates that 37\% of SNAP-receiving households in Seattle contain one or more person equal to or older than 60 years of age and $30 \%$ have children under the age of 18 . Additionally, $49 \%$ of all SNAP heads of households in Seattle are white. ${ }^{17}$

The Fresh Bucks users in this sample varied in reported length and amount of SNAP benefit receipt. Reported length of SNAP receipt was 6 months or less for 29\%, 6 months to 2 years for $32 \%$, and greater than 2 years for $39 \%$ of subjects. Participants reported 
monthly SNAP amounts of $\$ 150$ or less (33\%), $\$ 150$ to $\$ 200(45 \%)$, and over $\$ 200$ per month (22\%). For comparison, the maximum monthly SNAP benefit in Washington state is $\$ 189$ for a single person household, $\$ 347$ for a two person household, and $\$ 497$ for a three person household. ${ }^{18}$ The average monthly SNAP benefit for Washington households was $\$ 220$ in $2014 .{ }^{19}$ Finally, most study participants (80\%) did not report participation in other food assistance programs.

\section{Food security classifications of study respondents}

Based on responses in the pre-market survey, slightly less than half of all subjects (45\%) reported high or marginal food security, while 50 subjects $(28 \%)$ reported low food security and 50 subjects $(28 \%)$ reported very low food security. These data are in keeping with national trends. The United States Department of Agriculture (USDA) estimates that $46.3 \%$ of SNAP beneficiaries were food secure, while $27.8 \%$ experienced low food security and $25.9 \%$ experienced very low food security during 2014 . $^{1}$

\section{Differences in demographic characteristics by food security status}

Differences in demographic characteristics by food security status were significant for presence of children in the household $(P=0.02)$, gender $(P=0.01)$, language spoken at home $(P=0.02)$, and household size $(P=0.01)$ (Table 1$)$. Subjects reporting very low food security appeared more likely to have children compared to subjects reporting low or high/marginal food security $(38.8 \%, 16.3 \%$, and $20.3 \%$, respectively), although the majority of subjects were childless regardless of food security status. Subjects with very low food security were also more likely to be female ( $84 \%$ compared to $56 \%$ of low food security and $60 \%$ of high/marginal food secure participants), while high food security subjects appeared more likely to speak a language other than English (24\% compared to $8 \%$ of low food security and $10 \%$ of very low food security participants). We were unable to discern clear trends regarding household size.

Farmers market shopping frequency by food security status 
The majority (64\%) of participants reported shopping at farmers markets once a week or more, and only $3 \%$ of participants reported that this was their first time at the farmers market. However, frequency of shopping at a farmers market when in season significantly differed by food security status $(P=0.03)$ (Table 2$)$. Further investigation using a proportional odds regression model clarifies this relationship but finds it is nonsignificant. An unadjusted proportional odds regression model estimated that individuals with high/marginal food security have $106.3 \%$ higher odds of shopping at the market at least once per week than individuals with very low food security. The unadjusted model also estimated that individuals with high/marginal food security have $106.3 \%$ higher odds of shopping at the market at least once per month and of having shopped at the market before than individuals with low household food security. (OR=2.1, 95\% Confidence Interval $[\mathrm{CI}]=1.00-4.24, P=0.05$ ) (Table 3 ). An adjusted model estimated similar nonsignificant relationships after adjusting for gender, market site, number of children, household size, and whether English is spoken at home $(\mathrm{OR}=2.03, \mathrm{CI}=0.90-4.57$, $P=0.09)$.

Differences in shopping behaviors by food security status

No significant differences were noted between food security status and any other farmers market shopping behaviors included in the study (Table 1, Table 2).

\section{DISCUSSION}

Our results indicate that food security status amongst Fresh Bucks users mirrors national trends. Furthermore, the very low food security users in our sample were more likely to have children compared to users with low or high/marginal household food security and this is in keeping with national trends. However, in contrast to national trends, ethnicity and race showed no association with food security status in our sample. ${ }^{1}$

Regarding shopping frequency, our analysis found that individuals living in very low food secure households showed a trend toward shopping at the farmers market less 
frequently as compared with those of high/marginal food security. This relationship became insignificant after the model was adjusted for potential confounders. Several additional factors, including household location in relation to the markets, transportation, income, and job status, have been shown to differ with food security status. ${ }^{1,20}$ Although these variables could impact frequency of shopping at the farmers market, survey design limitations prevented their inclusion in the model. Further exploration of these potential factors is therefore warranted.

Interestingly, our data indicate that once present at the farmers market, Fresh Bucks users across all food security levels experience the market and the Fresh Bucks program in similar ways. Our analysis found no significant differences between food security status and all other variables assessed. These findings are surprising in light of previous research, which describes several differences in the dietary and shopping patterns of food insecure individuals compared to their food secure peers. A systemic review found that food insecure adults consume less fruits and vegetables compared to food secure adults. ${ }^{5}$ Previous research also demonstrates that food insecure individuals typically spend less on food while restricting food intake more frequently. ${ }^{1,8}$ Furthermore, qualitative research indicates that the least food secure individuals use strategies to avoid food shortage, including bargain hunting and menu planning, less frequently than their more food secure counterparts. It has been hypothesized that these more elaborate strategies may be less accessible to individuals with very low food security because of their less stable financial and living situations. ${ }^{8}$

The lack of demographic variation amongst subjects in our study sample may offer one possible explanation for the similarities across food security status categories illustrated by our data. The Fresh Bucks users in our study included a higher percentage of younger, white, and childless individuals as compared with Seattle-wide SNAP heads of households and this was true across all food security levels. It may be possible that Fresh Bucks users, or at least those in our sample, represent a group of SNAP users commonly referred to as able-bodied adults without dependents (ABAWDs). ABAWDs, defined as SNAP participants between the ages of 18 and 50 who are capable of employment and 
lack dependents, typically face restrictions on benefit length when not meeting work requirements. Several states, including Washington, have temporarily waived these restrictions in response to the recession. ${ }^{21,22}$ The similarities in Fresh Bucks shopping behaviors across users of all food security levels may therefore represent certain characteristics of the ABAWD population.

These findings should be considered in the context of several limitations. First, our data draws from a convenience sample and therefore may not be representative of all Fresh Bucks users. Individuals with limited English proficiency and less frequent users, in particular, may be under-represented. However, in an attempt to overcome this limitation and reach users with limited English proficiency, interviewers were hired who had Cantonese, Vietnamese, and Spanish language skills. Second, social desirability bias may have influenced participants' responses, particularly for potentially sensitive questions such as those related to food security. Third, seasonality may also have influenced participants' experience with the program and by extension their survey responses. Fourth, small sample size limits the strength of our conclusions and the generalizability of our results. However, this analysis serves as a preliminary exploration of the association between food security status and Fresh Bucks use. Finally, our study design does not allow for exploration of causation.

Future research should build upon our findings by confirming and clarifying these relationships in a larger sample. For example, future studies could analyze the relationship between farmers market shopping frequency and food security level with a larger sample size and in a broader population. Additionally, research could analyze potential barriers limiting frequency of farmers market use amongst very low food secure individuals. Such research could be used to increase access to farmers markets and ensure Fresh Bucks reaches the most vulnerable populations. 


\section{BIBLIOGRAPHY}

1. Coleman-Jensen A, Rabbitt MP, Nord M, Gregory C, Singh A. Household Food Security in the United States in 2014, ERR-194, U.S. Department of Agriculture, Economic Research Service, September 2015.

2. Definitions of Food Security. United States Department of Agriculture Economic Research Service Web site. Available at: http://www.ers.usda.gov/topics/foodnutrition-assistance/food-security-in-the-us/definitions-of-food-security.aspx. Accessed November 9, 2015.

3. Programs and Services. United States Department of Agriculture Food Nutrition Service Web site. Available at: http://www.fns.usda.gov/programs-and-services. Accessed November 9, 2015.

4. Drewnowski A, Specter SE. Poverty and obesity: The role of energy density and energy costs. Am J Clin Nutr. 2004;79:6-16. doi:10.1038/nrg1178.

5. Hanson KL, Connor LM. Food insecurity and dietary quality in US adults and children: a systematic review. Am J Clin Nutr. 2014;100:684-92.

doi:10.3945/ajen.114.084525.

6. Seligman HK, Laraia BA, Kushel MB. Food Insecurity Is Associated with Chronic Disease among Low-Income NHANES Participants. J Nutr. 2010;140:304-10. doi:10.3945/jn.109.112573.number.

7. Laraia B. Food Insecurity and Chronic Disease. Adv Nutr. 2013;4:203-12. doi:10.3945/an.112.003277.

8. U.S. Department of Agriculture, Food and Nutrition Service, Office of Research and Analysis, "SNAP Food Security In-Depth Interview Study," by Kathryn Edin, Melody Boyd, James Mabli,Jim Ohls, Julie Worthington, Sara Greene, Nicholas Redel, Swetha Sridharan. Project Officer: Sarah Zapolsky, Alexandria, VA: March 2013.

9. Fresh Bucks. Washington State Farmers Market Association Web site. Available at: http://www.wafarmersmarkets.com/foodaccess/freshbucks.html. Accessed November 4, 2015.

10. University of Washington Center for Public Health Nutrition. 2014 Fresh Bucks Evaluation; December 2014. 
11. J. Malbi, J. Ohls, L. Dragoset, L. Castner BS. SNAP Healthy Food Incentives Cluster Evaluation 2013 Final Report.; 2013.

12. Young CR, Aquilante JL, Solomon S, Colby L, Kawinzi MA, Uy N. Improving Fruit and Vegetable Consumption Among Low-Income Customers at Farmers Markets: Philly Food Bucks, Philadelphia, Pennsylvania, 2011. Prev Chronic Dis. 2013;10:E166. doi:10.5888/pcd10.120356.

13. Bartlett S, Klerman J, Olsho L, et al. Evaluation of the Healthy Incentives Pilot (HIP): Final Report. Prepared by Abt Associates for the U.S. Department of Agriculture, Food and Nutrition Service, September 2014.

14. Double Up Food Bucks 2012 Evaluation Report. Ann Arbor, MI; 2013.

15. United States Department of Agriculture Economic Research Service. U.S. Household Food Security Survey Module: Six-Item Short Form. September 2012.

16. R Core Team (2015). R: A language and environment for statistical computing. R Foundation for Statistical Computing, Vienna, Austria. URL http://www.Rproject.org/.

17. United States Census Bureau. Food Stamps/SNAP. In: 2011-2013 American Community Survey 3-Year Estimates for Seattle City Washington, editor. American Fact Finder

18. Washington State Department of Social \& Health Services Community Services Division. Washington Basic Food Program. Available at: http://foodhelp.wa.gov/bfqas.pdf. Accessed October 26, 2015.

19. Supplemental Nutrition Assistance Program (SNAP): National and/or State Level Monthly and/or Annual Data. United States Department of Agriculture Food and Nutrition Service Web site. Available at: http://www.fns.usda.gov/pd/supplemental-nutrition-assistance-program-snap. Accessed November 18, 2015.

20. Demartini TL, Beck AF, Kahn RS, Klein MD. Food Insecure Families: Description of Access and Barriers to Food from one Pediatric Primary Care Center. J Community Health. 2013;38:1182-1187. doi:10.1007/s10900-013-97318. 
21. Supplemental Nutrition Assistance Program (SNAP): Able-Bodied Adults Without Dependents (ABAWDs). United States Department of Agriculture Food and Nutrition Service Web site. Available at: http://www.fns.usda.gov/snap/ablebodied-adults-without-dependents-abawds. Accessed November 11, 2015.

22. United States Department of Agriculture. Status of State Able-bodied Adult without Dependents (ABAWD) Time Limit Waivers in Fiscal Year (FY) 2015. Available at:

http://www.fns.usda.gov/sites/default/files/snap/FY_2015_ABAWD_Waiver_Stat us.pdf Accessed November 11, 2015. 


\section{TABLES}

Table 1. Demographic Characteristics of Fresh Bucks Users by Food Security Status at 6 Seattle Farmers Markets at Time of Pre-Shopping Market Survey, Seattle, WA AugustSept $2014(\mathrm{n}=182)$

\begin{tabular}{|c|c|c|c|c|}
\hline Characteristic & $\begin{array}{l}\text { High or } \\
\text { Marginal Food } \\
\text { Security Users } \\
\text { No. }(\%)\end{array}$ & $\begin{array}{l}\text { Low Food } \\
\text { Security Users } \\
\text { No. }(\%)\end{array}$ & $\begin{array}{l}\text { Very Low } \\
\text { Food Security } \\
\text { Users No. }(\%)\end{array}$ & $P$ value \\
\hline Total & $82(100)$ & $50(100)$ & $50(100)$ & - \\
\hline \multicolumn{5}{|l|}{ Race $^{\mathrm{a}}$} \\
\hline White & $52(63.4)$ & $36(72.0)$ & $29(60.4)$ & \multirow[t]{6}{*}{$0.37^{b}$} \\
\hline Asian & $14(17.1)$ & $4(8.0)$ & $4(8.3)$ & \\
\hline $\begin{array}{l}\text { Black/African } \\
\text { American }\end{array}$ & $5(6.1)$ & $2(4.0)$ & $7(14.6)$ & \\
\hline $\begin{array}{l}\text { Combination of } \\
\text { races }\end{array}$ & $3(3.7)$ & $2(4.0)$ & $3(14.6)$ & \\
\hline $\begin{array}{l}\text { Native } \\
\text { Hawaiian/Pacific } \\
\text { Islander }\end{array}$ & $0(0.0)$ & $1(2.0)$ & $2(4.2)$ & \\
\hline $\begin{array}{l}\text { American } \\
\text { Indian/Alaska } \\
\text { Native }\end{array}$ & $1(1.2)$ & $0(0.0)$ & $0(0.0)$ & \\
\hline Other & $7(8.5)$ & $5(10.0)$ & $3(6.3)$ & \\
\hline \multicolumn{5}{|l|}{ Ethnicity } \\
\hline $\begin{array}{l}\text { Hispanic or } \\
\text { Latino }\end{array}$ & $7(8.6)$ & $4(8.0)$ & $4(8.2)$ & $>0.99^{\mathrm{b}}$ \\
\hline \multicolumn{5}{|c|}{ Language spoken at home ${ }^{\mathrm{a}}$} \\
\hline English & $62(75.6)$ & $46(92.0)$ & $43(89.6)$ & \multirow[t]{2}{*}{$0.02^{b}$} \\
\hline Other & $20(24.4)$ & $4(8.0)$ & $5(10.4)$ & \\
\hline \multicolumn{5}{|l|}{ Gender $^{\mathrm{a}}$} \\
\hline Male & $30(37.0)$ & $20(40.0)$ & $7(14.0)$ & \multirow[t]{3}{*}{$0.01^{\mathrm{b}}$} \\
\hline Female & $49(60.5)$ & $28(56.0)$ & $42(84.0)$ & \\
\hline $\begin{array}{l}\text { Neither of the } \\
\text { above }\end{array}$ & $2(2.5)$ & $2(4.0)$ & $1(2.0)$ & \\
\hline \multicolumn{5}{|c|}{ Number of children under the age of 18 present in household ${ }^{\mathrm{a}}$} \\
\hline 0 & $63(79.8)$ & $41(83.7)$ & $30(61.2)$ & \multirow[t]{2}{*}{$0.02^{c}$} \\
\hline $1-6$ & $16(20.3)$ & $8(16.3)$ & $19(38.8)$ & \\
\hline \multicolumn{5}{|l|}{ Household size } \\
\hline 1 & $34(41.5)$ & $28(56.0)$ & $19(38.0)$ & \multirow[t]{4}{*}{$0.01^{b}$} \\
\hline 2 & $21(25.6)$ & $8(16.0)$ & $13(26.0)$ & \\
\hline $3-5$ & $26(31.7)$ & $7(14.0)$ & $14(28.0)$ & \\
\hline 6 or more & $1(1.2)$ & $7(14.0)$ & $4(8.0)$ & \\
\hline \multicolumn{5}{|l|}{$\operatorname{Age}^{\mathrm{a}}$} \\
\hline $18-30$ & $34(42.0)$ & $16(32.0)$ & $17(34.0)$ & $0.33^{b}$ \\
\hline
\end{tabular}




\begin{tabular}{|c|c|c|c|c|}
\hline $31-50$ & $24(29.6)$ & $20(40.0)$ & $22(44.0)$ & \\
\hline $51-65$ & $14(17.3)$ & $11(22.0)$ & $10(20.0)$ & \\
\hline$\geq 65$ & $9(11.1)$ & $3(6.0)$ & $1(2.0)$ & \\
\hline \multicolumn{5}{|c|}{ Highest level of education ${ }^{\mathrm{a}}$} \\
\hline $\begin{array}{l}\text { Some high } \\
\text { school }\end{array}$ & $2(2.4)$ & $1(2.1)$ & $1(2.0)$ & \multirow[t]{5}{*}{$0.63^{\mathrm{b}}$} \\
\hline $\begin{array}{l}\text { Completed high } \\
\text { school }\end{array}$ & $5(6.1)$ & $8(16.7)$ & $7(14.3)$ & \\
\hline Some college & $18(22.0)$ & $12(25.0)$ & $14(28.6)$ & \\
\hline $\begin{array}{l}\text { Completed } \\
\text { college }\end{array}$ & $41(50.0)$ & $19(39.6)$ & $20(40.9)$ & \\
\hline Post-college & $16(19.5)$ & $8(16.7)$ & $7(14.3)$ & \\
\hline \multicolumn{5}{|c|}{ Monthly SNAP/EBT benefits ${ }^{\mathrm{a}}$} \\
\hline$\leq \$ 150$ & $29(35.8)$ & $14(29.2)$ & $16(32.0)$ & \multirow[t]{3}{*}{$0.54^{\mathrm{c}}$} \\
\hline$\$ 150 \geq \$ 200$ & $35(43.2)$ & $26(54.2)$ & $20(40.0)$ & \\
\hline$>\$ 200$ & $17(21.0)$ & $8(16.7)$ & $14(28.0)$ & \\
\hline \multicolumn{5}{|c|}{ Length of time receiving SNAP/EBT ${ }^{\mathrm{a}}$} \\
\hline 6 months or less & $24(30.0)$ & $14(28.6)$ & $14(28.0)$ & \multirow[t]{6}{*}{$0.99^{\mathrm{c}}$} \\
\hline $\begin{array}{l}6 \text { months }>1 \\
\text { year }\end{array}$ & $10(12.5)$ & $9(18.4)$ & $7(14.0)$ & \\
\hline 1 year $>2$ years & $14(17.5)$ & $7(14.3)$ & $11(22.0)$ & \\
\hline 2 years $>3$ years & $9(11.3)$ & $6(12.2)$ & $6(12.0)$ & \\
\hline 3 years $>5$ years & $9(11.3)$ & $6(12.2)$ & $6(12.0)$ & \\
\hline $\begin{array}{l}\text { more than } 5 \\
\text { years }\end{array}$ & $14(17.5)$ & $7(14.3)$ & $6(12.0)$ & \\
\hline \multicolumn{5}{|c|}{ Participation in other food assistance programs ${ }^{\mathrm{a}}$} \\
\hline None & $69(84.2)$ & $41(83.7)$ & $34(69.4)$ & \multirow[t]{4}{*}{$0.23^{\mathrm{b}}$} \\
\hline Other & $9(11.0)$ & $4(8.2)$ & $11(22.5)$ & \\
\hline WIC FMNP & $3(3.7)$ & $4(8.2)$ & $3(6.1)$ & \\
\hline Senior FMNP & $1(1.2)$ & $0(0.0)$ & $1(2.0)$ & \\
\hline
\end{tabular}

Abbreviations: SNAP, Supplemental Nutrition Assistance Program; EBT, Electronic Benefit Transfer; WIC, Women Infants and Children; FMNP, Farmers Market Nutrition Program

a: sample does not total 182 due to incomplete or missing data

b: $p$-value calculated using fisher exact test

c: p-value calculated using chi-squared test 
Table 2. Farmers Market Shopping Characteristics of Fresh Bucks Users by Food Security Status at 6 Seattle Farmers Markets at Time of Pre-Shopping Market Survey, Post-Shopping Market Survey, and Telephone Follow-Up Survey; Seattle, WA AugustOctober 2014 ( $\mathrm{n}=182,153$, and 80 respectively)

\begin{tabular}{|l|l|l|l|l|}
\hline $\begin{array}{l}\text { Survey } \\
\text { Question }\end{array}$ & $\begin{array}{l}\text { High or } \\
\text { Marginal Food } \\
\text { Security Users } \\
\text { No.(\%) }\end{array}$ & $\begin{array}{l}\text { Low Food } \\
\text { Security Users } \\
\text { No. (\%) }\end{array}$ & $\begin{array}{l}\text { Very Low Food } \\
\text { Security Users } \\
\text { No. (\%) }\end{array}$ & $P$ value \\
\hline
\end{tabular}

Farmers Market Characteristics at Time of Pre-Shopping Market Survey (August-Sept 2014, $\mathrm{n}=182$ )

\begin{tabular}{|l|l|l|l} 
Total & $82(100)$ & $50(100)$ & $50(100)$
\end{tabular}

\begin{tabular}{|c|c|c|c|c|}
\hline First time & $1(1.2)$ & $0(0.0)$ & $4(8.0)$ & \multirow[t]{4}{*}{$0.037^{b}$} \\
\hline $\begin{array}{l}\text { Once a week or } \\
\text { more }\end{array}$ & $55(67.1)$ & $31(63.3)$ & $28(56.0)$ & \\
\hline $\begin{array}{l}\text { Once or twice a } \\
\text { month }\end{array}$ & $24(29.3)$ & $16(32.7)$ & $11(22.0)$ & \\
\hline $\begin{array}{l}\text { Less than once } \\
\text { a month }\end{array}$ & $2(2.4)$ & $2(4.1)$ & $7(14.0)$ & \\
\hline
\end{tabular}

How many times have you ever used Fresh Bucks before today-including this year and all prior years? ${ }^{\mathrm{a}}$

\begin{tabular}{|c|c|c|c|c|}
\hline First time & $15(18.3)$ & $6(12.0)$ & $10(20.4)$ & \multirow[t]{3}{*}{$0.77^{\mathrm{c}}$} \\
\hline $1-4$ & $15(18.3)$ & $11(22.0)$ & $11(22.5)$ & \\
\hline More than 5 & $52(63.4)$ & $33(66.0)$ & $28(57.1)$ & \\
\hline
\end{tabular}

Since you learned about the Fresh Bucks program, have you shopped at farmers markets the same amount, more, or less?

\begin{tabular}{|c|c|c|c|c|}
\hline $\begin{array}{l}\text { I go a lot more } \\
\text { often }\end{array}$ & $46(65.7)$ & $32(71.1)$ & $25(61.0)$ & $0.81^{b}$ \\
\hline $\begin{array}{l}\text { I go a little } \\
\text { more often }\end{array}$ & $16(22.9)$ & $8(17.8)$ & $12(29.3)$ & \\
\hline $\begin{array}{l}\text { I go about the } \\
\text { same }\end{array}$ & $8(11.4)$ & $5(11.1)$ & $4(9.8)$ & \\
\hline
\end{tabular}

\begin{tabular}{|c|c|c|c|c|}
\hline \multicolumn{5}{|c|}{$\begin{array}{l}\text { About how much of the fruits and vegetables that you bought in the last month did } \\
\text { you buy at a farmers market? }\end{array}$} \\
\hline $3 / 4$ or greater & $34(41.5)$ & $25(52.1)$ & $19(38.8)$ & \multirow[t]{3}{*}{$0.24^{\mathrm{c}}$} \\
\hline About $1 / 2$ & $18(22.0)$ & $12(25.0)$ & $8(16.3)$ & \\
\hline $1 / 4$ or less & $30(36.6)$ & $11(22.9)$ & $22(44.9)$ & \\
\hline
\end{tabular}

Would you say you buy the same amount of fruits and vegetables in a given month when you use the Fresh Bucks program, or more? ${ }^{\text {a }}$

\begin{tabular}{|c|c|c|c|c|}
\hline A lot more & $25(35.7)$ & $22(48.9)$ & $22(55.0)$ & \multirow[t]{4}{*}{$0.33^{b}$} \\
\hline $\begin{array}{l}\text { Somewhat } \\
\text { more }\end{array}$ & $28(40.0)$ & $14(31.1)$ & $13(32.5)$ & \\
\hline A little more & $7(10.0)$ & $5(11.1)$ & $4(10.0)$ & \\
\hline No more & $10(14.3)$ & $4(8.9)$ & $1(2.5)$ & \\
\hline
\end{tabular}




\begin{tabular}{|c|c|c|c|c|}
\hline \multicolumn{5}{|c|}{ (August-Sept 2014, $\mathrm{n}=153$ ) } \\
\hline Total & $70(100)$ & $43(100)$ & $40(100)$ & - \\
\hline \multicolumn{5}{|c|}{ Did you buy any fruits or vegetables today that you don't usually purchase ${ }^{d}$} \\
\hline Yes & $34(49.3)$ & $28(65.1)$ & $24(63.2)$ & \multirow[t]{2}{*}{$0.18^{\mathrm{c}}$} \\
\hline No & $35(50.7)$ & $15(34.9)$ & $14(36.8)$ & \\
\hline \multicolumn{5}{|c|}{ How did you pay for your items at the market today? } \\
\hline $\begin{array}{l}\text { Fresh Bucks } \\
\text { and EBT only }\end{array}$ & $44(62.9)$ & $28(65.1)$ & $24(60)$. & \multirow[t]{3}{*}{$0.98^{\mathrm{b}}$} \\
\hline $\begin{array}{l}\text { Cash, Debit, or } \\
\text { Credit Card }\end{array}$ & $24(34.3)$ & $14(32.6)$ & $15(37.5)$ & \\
\hline $\begin{array}{l}\text { Other } \\
\text { assistance } \\
\text { program }\end{array}$ & $2(2.9)$ & $1(2.3)$ & $1(2.5)$ & \\
\hline \multicolumn{5}{|c|}{ Did you have any EBT currency or Fresh Bucks left over after shopping? } \\
\hline Yes & $37(0.52 .9)$ & $18(41.9)$ & $21(52.5)$ & \multirow[t]{2}{*}{$0.48^{\mathrm{c}}$} \\
\hline No & $33(47.1)$ & $25(58.1)$ & $19(47.5)$ & \\
\hline \multicolumn{5}{|c|}{$\begin{array}{l}\text { Farmers Market Characteristics at Time of Telephone Follow-Up Survey } \\
\text { (n=80, Oct-Nov 2014) }\end{array}$} \\
\hline Total & $37(100)$ & $19(100)$ & $24(100)$ & - \\
\hline \multicolumn{5}{|c|}{ Returned to use Fresh Bucks between market and telephone survey? } \\
\hline Yes & $31(83.8)$ & $16(84.2)$ & $20(83.3)$ & \multirow[t]{2}{*}{$>0.99^{b}$} \\
\hline No & $6(16.2)$ & $3(15.8)$ & $4(16.7)$ & \\
\hline \multicolumn{5}{|c|}{$\begin{array}{l}\text { How likely is it that you will shop at one of the four year-long farmers markets after } \\
\text { the Fresh Bucks program ends? }\end{array}$} \\
\hline Very likely & $23(62.2)$ & $10(55.6)$ & $11(45.8)$ & \multirow[t]{4}{*}{$0.29^{b}$} \\
\hline A little likely & $7(18.9)$ & $3(16.7)$ & $9(37.5)$ & \\
\hline Unlikely & $1(2.7)$ & $0(0.0)$ & $2(8.3)$ & \\
\hline Very unlikely & $6(16.2)$ & $5(2.8)$ & $2(8.3)$ & \\
\hline \multicolumn{5}{|c|}{$\begin{array}{l}\text { In general, how many of the fruits and vegetables that you bought with Fresh Bucks } \\
\text { did you know how to prepare when you bought them? }\end{array}$} \\
\hline All of them & $30(81.1)$ & $15(79.0)$ & $13(54.2)$ & \multirow[t]{4}{*}{$0.16^{\mathrm{b}}$} \\
\hline More than half & $6(16.2)$ & $4(21.1)$ & $7(29.2)$ & \\
\hline About half & $1(2.7)$ & $0(0.0)$ & $2(8.3)$ & \\
\hline Less than half & $0(0.0)$ & $0(0.0)$ & $2(8.3)$ & \\
\hline \multicolumn{5}{|c|}{$\begin{array}{l}\text { In general, how many of the fruits and vegetables that you bought with Fresh Bucks } \\
\text { were you able to finish before they went bad? }\end{array}$} \\
\hline All of them & $23(62.2)$ & $11(57.9)$ & $13(54.2)$ & \multirow[t]{3}{*}{$0.46^{\mathrm{b}}$} \\
\hline More than half & $14(37.8)$ & $8(42.1)$ & $9(37.5)$ & \\
\hline About half & $0(0.0)$ & $0(0.0)$ & $2(8.3)$ & \\
\hline
\end{tabular}

Abbreviations: EBT, Electronic Benefit Transfer

a: sample does not total 182 due to incomplete or missing data

$\mathrm{b}$ : $\mathrm{p}$-value calculated using fisher exact test

c: $p$-value calculated using chi-squared test

d: sample does not total 153 due to incomplete or missing data

e: sample does not total 80 due to incomplete or missing data 
Table 3. Associations Between Food Security Level and Farmers Market Shopping Frequency Among Fresh Bucks Users at 6 Seattle Farmers Markets at Time of PreShopping Market Survey Based on Estimates of Proportional Odds Regression Models, Seattle WA August-Sept 2014

\begin{tabular}{|c|c|c|c|c|}
\hline \multirow[t]{2}{*}{ Variable } & \multicolumn{2}{|c|}{$\begin{array}{l}\text { Unadjusted Model } \\
(\mathrm{n}=181)\end{array}$} & \multicolumn{2}{|c|}{$\begin{array}{l}\text { Adjusted }^{\mathrm{a}} \text { Model } \\
(\mathrm{n}=168)\end{array}$} \\
\hline & $\begin{array}{l}\text { OR }(95 \% \\
\mathrm{CI})\end{array}$ & $P$ value & $\begin{array}{l}\text { OR }(95 \% \\
\mathrm{CI})\end{array}$ & $P$ value \\
\hline Very Low & \multicolumn{2}{|l|}{ Reference } & \multicolumn{2}{|l|}{ Reference } \\
\hline Low & $\begin{array}{l}1.8(0.80- \\
3.94)\end{array}$ & 0.16 & $\begin{array}{l}1.7(0.71- \\
4.07)\end{array}$ & 0.23 \\
\hline High/Marginal & $\begin{array}{l}2.1(1.00- \\
4.24)\end{array}$ & 0.05 & $\begin{array}{l}2.3(0.89- \\
4.57)\end{array}$ & 0.09 \\
\hline Male & - & - & $\begin{array}{l}0.8(0.40- \\
1.65)\end{array}$ & 0.56 \\
\hline Market location 1 & - & - & Reference & Reference \\
\hline Market location 2 & - & - & $\begin{array}{l}0.3(0.08- \\
1.22)\end{array}$ & 0.09 \\
\hline Market location 3 & - & - & $\begin{array}{l}0.6(0.23- \\
1.71)\end{array}$ & 0.36 \\
\hline Market location 4 & - & - & $\begin{array}{l}0.1(0.03- \\
0.45)\end{array}$ & 0.002 \\
\hline Market location 5 & - & - & $\begin{array}{l}2.0(0.30- \\
13.5)\end{array}$ & 0.47 \\
\hline Market location 6 & - & - & $\begin{array}{l}0.5(0.22- \\
1.33)\end{array}$ & 0.18 \\
\hline Number of children & - & - & $\begin{array}{l}0.8(0.55- \\
1.16)\end{array}$ & 0.24 \\
\hline Household size & - & - & $\begin{array}{l}0.9(0.83- \\
1.02)\end{array}$ & 0.11 \\
\hline English & - & - & $\begin{array}{l}2.9(0.95- \\
9.04)\end{array}$ & 0.06 \\
\hline
\end{tabular}

a: Model adjusted for market location, gender, number of children, household size, and language spoken at home 